\title{
Effect of infection by the metacercarial trematode Renicola roscovita on growth in intertidal blue mussel Mytilus edulis
}

\author{
David W. Thieltges*
}

Alfred Wegener Institute for Polar and Marine Research, Wadden Sea Station Sylt, Hafenstrasse 43, 25992 List, Germany

\begin{abstract}
Trematode parasites can affect the molluscan hosts serving as first intermediate hosts in their complex life-cycles in manifold ways, but little is known about trematode-induced effects in second intermediate mollusc hosts. In 2 field experiments in 2 habitats and at 2 tidal heights (low and mid intertidal), controlled infection of blue mussels Mytilus edulis serving as second intermediate hosts for larval stages (metacercariae) of the trematode Renicola roscovita resulted in significant lower growth of parasitized compared to non-parasitized individuals. However, tidal height had a stronger effect on mussel growth than parasitism, without any interaction between the 2 factors. The negative effect of $R$. roscovita metacercarial infections on mussel growth is thought to result from direct tissue disruptions, interference of metacercariae (located in palps and visceral mass) with food intake ability, and growth of metacercarial cysts within the host. Mussel growth was negatively correlated with the number of metacercariae, but this relation was significant only at the mid and not at the low intertidal sites. This may indicate that parasites act as background stressors that affect their hosts depending on additional environmental stress such as (e.g.) food shortage, desiccation and heat, which all increase with the increasing aerial exposure. The results of this study show that trematode infections can be an important determinant of bivalve growth, with potential economic implications for mussel cultivation.
\end{abstract}

KEY WORDS: Trematodes $\cdot$ Bivalves $\cdot$ Growth $\cdot$ Parasites $\cdot$ Field experiment $\cdot$ Controlled infections

\section{INTRODUCTION}

Trematode parasites have been shown to affect their marine mollusc hosts in manifold ways. In the complex life cycles of marine trematodes, molluscs serve as first intermediate hosts and, besides other invertebrates and fishes, also as second intermediate hosts. Final hosts of trematodes are vertebrates (Lauckner 1980, 1983). Particularly well studied are the effects of trematodes utilizing molluscs as first intermediate hosts. The extensive reproduction of the parasites inside the host tissue, often filling large parts of the host body, results in dramatic effects such as castration and enhanced mortality, and also affects host growth (Lauckner 1980, Mouritsen \& Poulin 2002). Growth rates of gastropods serving as first intermediate hosts can be enhanced (gigantism) (Rothschild 1936, Mouritsen \& Jensen 1994), reduced (Sousa 1983, Mouritsen et al. 1999) or not affected (Hughes \& Answer 1982, Siddall et al. 1993, Mouritsen et al. 1999). In general, it is thought that in short-lived snails (e.g. Hydrobia spp.) castration by trematodes results in gigantism, while in longer-lived hosts (e.g. Littorina spp., Cerithidea californica, Ilyanassa obsoleta) no or negative effects occur (Sousa 1983, Mouritsen \& Poulin 2002). However, factors other than life history characteristics of hosts seem to be important determinants of effects of trematode infections in first intermediate hosts, e.g. the trematode species involved, the host's food supply and exploitative competition between conspecifics (Mouritsen \& Jensen 1994, Mouritsen et al. 1999, Mouritsen \& Poulin 2002).

The effects of trematodes utilizing molluscs as second intermediate hosts are known to a much lesser extent. In this case, the effects seem to be less dramatic, 
since metacercariae do not reproduce in the host and thus are not as tissue destructive as their sporocyst counterparts in first intermediate mollusc hosts (Lauckner 1980, 1983, Mouritsen \& Poulin 2002). However, in combination with other stressors, trematodes may affect survival of their second intermediate host (e.g. Wegeberg \& Jensen 1999). The host's growth rates may also be affected: Lim \& Green (1991) found enhanced growth in Macoma balthica parasitized by metacercariae of several species. In contrast, reduced growth was detected in Cerastoderma edule infected with Himasthla interrupta (Wegeberg \& Jensen 2003) and in Perna perna infected with Proctoeces sp. (Calvo-Ugarteburu \& McQuaid 1998). However, quantitative data on the effects of parasite species on their second intermediate mollusc hosts are largely lacking, and hence our knowledge on parasites as determinants of mollusc growth is limited. Another limitation is methodological: except for a few studies (e.g. Wegeberg \& Jensen 2003), conclusions have been drawn from field observations or from experiments using parasitized and non-parasitized individuals collected in the field, with no controls for other potential factors underlying the infections or affecting growth. An appropriate solution to this limitation is controlled, artificial infection of experimental individuals.

The blue mussel Mytilus edulis, an ecologically and commercially important epibenthic bivalve species, often occurs in mussel beds as well as in small clumps or as single individuals on hard bottoms and sand flats. In northern Europe, it is frequently parasitized by the trematode Renicola roscovita (Lauckner 1983, Buck et al. 2005). $R$. roscovita utilizes the periwinkle gastropod Littorina littorea as the first intermediate host for its life cycle and a range of bivalves as the second intermediate host (Lauckner 1980, 1983). Several thousand encysted metacercariae can occur in individual mussels, predominantly in the palps and the visceral mass (Lauckner 1983, Buck et al. 2005). A variety of factors such as salinity, temperature, current velocity, epigrowth and competition for substrate or food are known to influence mussel growth, with duration of emersion and contact with filterable food being probably the most important contributory factors in intertidal environments (Baird 1966, Okamura 1986, Seed \& Suchanek 1992, Buschbaum \& Saier 2001). Although it frequently occurs in mussels, the potential effects of this parasite species on growth of its host have not been studied. Using controlled infections of $M$. edulis with $R$. roscovita, this study tested the effects of infection by the trematode $R$. roscovita on growth of the blue mussel at 2 field sites and 2 tidal levels. One field site was a mussel bed, the other a sand flat. The latter site was chosen to examine the potential natural infection of non-parasitized mussels through a high abun- dance of periwinkles, the trematode's first intermediate host. On the sand flat no periwinkles were present and thus no natural infection by $R$. roscovita expected.

\section{MATERIALS AND METHODS}

Study site. Both experiments were conducted in a tidal inlet, Königshafen, on the north coast of the island of Sylt (North Sea, Germany) on a mussel Mytilus edulis bed and a sand flat. This tidal inlet is part of a tidal basin in the northern Wadden Sea. The tides in this basin are semidiurnal, with a mean range of $2 \mathrm{~m}$. Salinity remains close to 30 . Mean water temperature is $15^{\circ} \mathrm{C}$ in summer and $4^{\circ} \mathrm{C}$ in winter. Tidal flats comprise $33 \%$ of the area, with sand being the prevailing sediment type $(72 \%$ of the total intertidal). M. edulis beds cover approximately $3 \%$ of the intertidal area.

Parasite and host material. Mussels Mytilus edulis (15 to $20 \mathrm{~mm}$ ) were randomly collected from a buoy (not treated with antifouling paint) in front of the tidal inlet Königshafen, where experiments were conducted. Because of the absence of the intermediate snail hosts mussels at this site are known to be free of trematode infections. To confirm the absence of parasites, tissues from 50 mussels were placed between 2 large glass slides and examined for trematode infection under a dissection microscope. The remaining mussels were kept in a large flow-through aquarium (3 $\mathrm{m}$ diameter). To obtain parasitized snails for controlled infections, periwinkles Littorina littorea were randomly collected near the mussel bed. In the laboratory, these were placed in bowls filled with aerated sea water (approx. $20^{\circ} \mathrm{C}$ ) and exposed to light for several hours. The water was then screened for the presence of emerged cercariae. Renicola roscovita-infected and uninfected periwinkles were then isolated and kept separately in large aerated aquaria (100 l) until the controlled infection was initiated.

Controlled infections and experimental design. Infection of mussels with metacercariae of Renicola roscovita was achieved by placing 5 mussels and 5 infected Littorina littorea in a bowl $(400 \mathrm{ml})$ filled with sea water (approx. $20^{\circ} \mathrm{C}$ ) and equipped with an air pump. In a second (control) treatment, 5 mussels and 5 uninfected snails were kept together in identical bowls to control for potential effects of snail presence on mussels. After $12 \mathrm{~h}$, the snails in both treatments (parasitized and non-parasitized) were removed and the mussels were kept in the bowls for another $12 \mathrm{~h}$ to ensure encystment of metacercariae (authors' pers. obs.). Following this procedure, the mussels were kept in a large flow-through aquarium for a maximum of $3 \mathrm{~d}$ until the start of experiments. 
At the start of the field experiments, infected and uninfected mussels were measured with a calliper to the nearest $0.1 \mathrm{~mm}$. A single mussel was placed in a small cage $(10 \mathrm{~cm}$ diameter, $10 \mathrm{~cm}$ height) made of polypropylene with a mesh size of $5 \mathrm{~mm}$ and mounted on a wooden board. On the mussel bed (entrance of the tidal inlet), I fixed 40 cages (20 replicates per treatment) with rods at the mean low water line (MLW) (low site) and 40 cages in the mid intertidal at the highest part of the bed (+0.5 m MLW) (mid site). The cages were placed approximately $50 \mathrm{~cm}$ apart on the top layer of mussels in a completely random design. On the sand flat (inner part of the tidal inlet), I fixed 30 cages (15 replicates per treatment) with rods on the sediment in the low intertidal (+0.2 $\mathrm{m} \mathrm{MLW)}$ (low site) and 30 cages in the mid intertidal (+1 $\mathrm{m}$ MLW) (mid site). The cages were placed approximately $50 \mathrm{~cm}$ apart in a completely random design. The experiments started on 5 June 2004 and were terminated 10 wk later in August. Mean water temperature during the experiments was 15 to $21^{\circ} \mathrm{C}$; salinity remained around 30 . At the end of the experiments, the length of each mussel (maximum anteriorposterior axis) was measured with a calliper to the nearest $0.1 \mathrm{~mm}$. The tissue of each mussel was carefully removed, placed between 2 large glass slides, and examined under a dissection microscope for trematode infection. All metacercariae were identified (Lauckner 1980, 1983) and counted.

Statistical analysis. Parasite recruitment to the mussel bed was unexpectedly low (indicated by similar infection rates of the originally non-parasitized mus- sels at the 2 experimental sites) during the experiment so that data from both sites could be used for analysis. Results are shown as mean $( \pm \mathrm{SE})$ infection intensity (number of parasite individuals per infected host) (sensu Bush et al. 1997) (see Fig. 1). To compare growth rates between treatments, analysis of covariance (ANCOVA) was applied with $\log _{10}$ (initial mussel length) as covariate and tidal height and parasitism as fixed factors in a 2-factor crossed design. Shell growth was $\log _{10}$-transformed prior to all analyses to meet assumptions of normality and homogeneity of variances (visual inspection and Cochran's C-test). Relations between parasite $\operatorname{load}\left(\log _{10}+1\right)$ and growth $\left(\log _{10}\right)$ were analyzed by linear regression. All calculations were carried out with the software STATISTICA (StatSoft).

\section{RESULTS AND DISCUSSION}

In both experiments, parasite infection and tidal height had a significant effect on mussel growth, but there were no interactions (Fig. 1, Table 1). Nonparasitized mussels grew better than mussels infected with Renicola roscovita, and mussels at the low intertidal sites grew better than mussels at the mid intertidal sites. On the mussel bed, growth of parasitized individuals at the mid site $(7.8 \pm 0.3 \mathrm{~mm})$ was $14 \%$ lower than that of non-parasitized individuals $(9 \pm 0.3 \mathrm{~mm})$. Parasitized mussels at the low site $(11.9 \pm 0.2 \mathrm{~mm})$ grew $5 \%$ less than non-parasitized mussels $(12.5 \pm 0.4 \mathrm{~mm})$. On the sand flat, growth of parasitized mussels at the mid
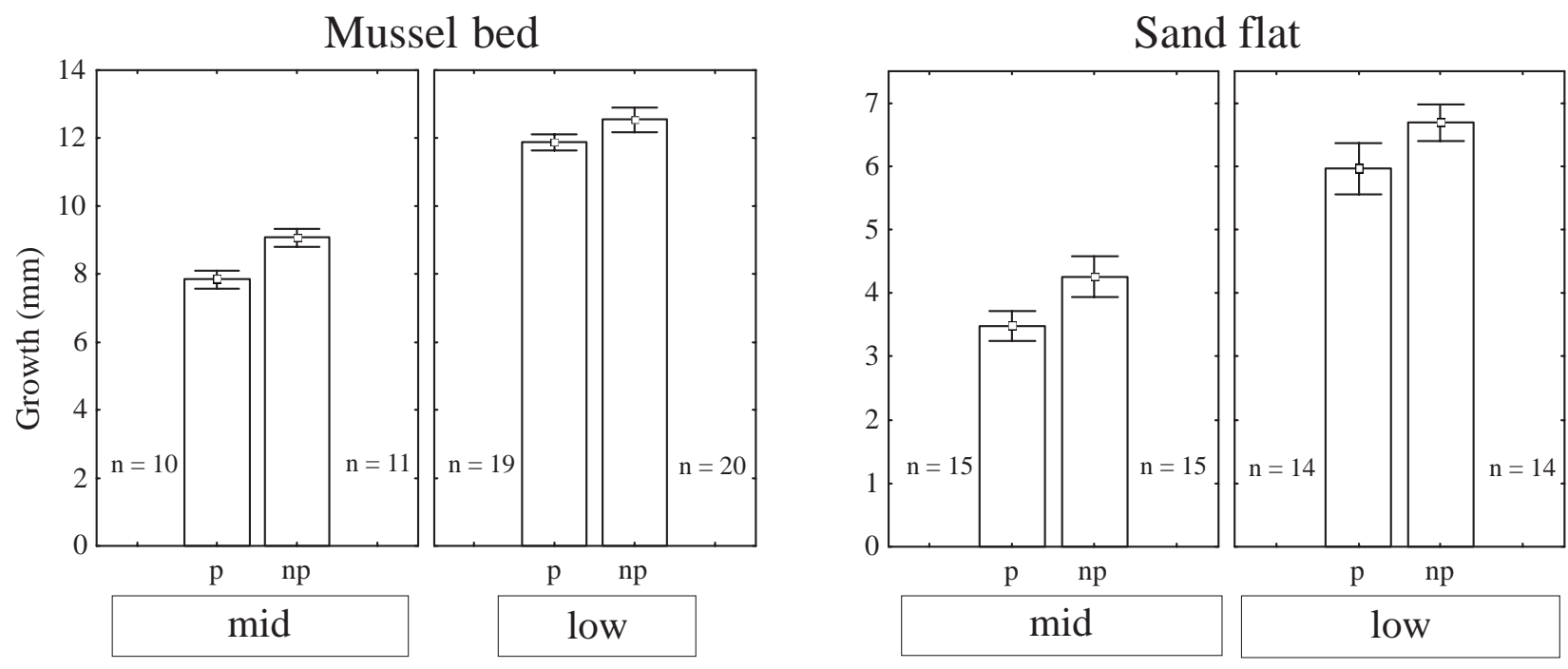

Fig. 1. Mytilus edulis. Mean ( \pm SE) growth of mussels parasitized (p) with metacercariae of Renicola roscovita and non-parasitized (np) mussels at low and mid intertidal sites in 2 experiments (mussel bed, sand flat) at the end of 10 wk exposure. Due to cage loss, final replicates $(n=$ no. of mussels per treatment) differed between treatments 
Table 1. Mytilus edulis. Results of analysis of covariance (ANCOVA) with log initial shell length as covariate for effects of tidal height (low, mid), and parasites Renicola roscovita (parasitized, non-parasitized) as fixed factors on log growth. Significant $p$-values are in boldface

\begin{tabular}{|lrrrl|}
\hline Parameter & df & MS & $F$ & $\mathrm{p}$ \\
\hline Mussel bed & & & & \\
$\quad$ Tidal height (T) & 1 & 0.313 & 155.8 & $\mathbf{< 0 . 0 0 1}$ \\
Parasites (P) & 1 & 0.015 & 7.6 & $\mathbf{< 0 . 0 1}$ \\
T $\times$ P & 1 & 0.003 & 1.5 & $=0.23$ \\
Log initial length & 1 & 0.016 & 8.1 & $\mathbf{< 0 . 0 1}$ \\
Total & 55 & 0.002 & & \\
Sand flat & & & & \\
$\quad$ Tidal height (T) & 1 & 0.639 & 45.7 & $<\mathbf{0 . 0 0 1}$ \\
Parasites (P) & 1 & 0.059 & 4.2 & $<\mathbf{0 . 0 5}$ \\
T $\times$ P & 1 & 0.003 & 0.2 & $=0.66$ \\
Log initial length & 1 & 0.006 & 0.4 & $=0.51$ \\
Total & 55 & 0.014 & & \\
\hline
\end{tabular}

site $(3.5 \pm 0.2 \mathrm{~mm})$ was $18 \%$ lower than that of nonparasitized mussels $(4.3 \pm 0.3 \mathrm{~mm})$. Growth of parasitized mussels at the low site $(5.7 \pm 0.4 \mathrm{~mm})$ was $11 \%$ lower than that of non-parasitized mussels (6.7 \pm $0.3 \mathrm{~mm}$ ). Loss of cages due to storms caused a reduction in the original numbers of replicates (Fig. 1). The growth of individual mussels $\left(\log _{10}\right)$ was only significantly and negatively correlated with the number of $R$. roscovita metacercariae present $\left(\log _{10}+1\right)$ at the mid-intertidal sites (mussel bed: $\mathrm{r}^{2}=0.32$, $\mathrm{p}<0.001$; sand flat: $\left.\mathrm{r}^{2}=0.14, \mathrm{p}<0.05\right)$ but not at the low-intertidal sites (mussel bed: $\mathrm{r}^{2}=0.04, \mathrm{p}=0.22$; sand flat: $\mathrm{r}^{2}=0.06$, $\mathrm{p}=0.20)$.

Controlled infections proved to be successful, since all artificially infected mussels bore metacercariae of Renicola roscovita (mean $=334 \pm 270$ metacercariae mussel $^{-1}$ ). Metacercariae occurred predominantly (>90\% of total $R$. roscovita metacercariae per host) in the palps and the visceral mass of infected individuals. Prior to the experiments, the mussels had been free of parasites (confirmed by microscopic examination of 50 sub-sampled individuals). Natural infections with Renicola roscovita in the non-parasitized treatments during the experimental period occurred on the mussel bed in $61 \%$ of the mussels. However, intensities were generally low $\left(2.3 \pm 2.2\right.$ metacercariae infected mussel $\left.{ }^{-1}\right)$. In the mid-intertidal of the sand flat, natural infections with Himasthla continua occurred in $73 \%$ of parasitized and non-parasitized mussels $(2.5 \pm 1.4$ metacercariae infected mussel ${ }^{-1}$ ).

Controlled infection with metacercariae of Renicola roscovita resulted in up to an almost $20 \%$ lower growth increment in parasitized Mytilus edulis compared to non-parasitized mussels within a period of $10 \mathrm{wk}$. This effect was independent of tidal height and experimental site. There are 3 mechanisms that are likely to be responsible for the observed growth reduction in infected mussels: (1) the invasion of the mussel tissues by cercariae with subsequent encystment, since metacercariae lead to tissue destruction and local inflammation (Lauckner 1983, Villalba et al. 1997), thus imposing a physiological burden on the mussels; (2) the encystment by metacercariae of $R$. roscovita in $M$. edulis predominantly in the palps and the visceral mass (Lauckner 1983, Buck et al. 2005, authors' pers. obs.), which both play an important role in the feeding and metabolic processes of bivalves (Hawkins et al. 1998); (3) growth of $R$. roscovita during the encysted metacercarial stage (Lauckner 1980, 1983, author's pers. obs.) which could result in a higher defense response of mussels and a higher energy demand by $R$. roscovita compared to non-growing metacercarial cysts of other trematode species. These characteristics of $R$, roscovita metacercariae may explain the greater effect of $R$. roscovita on bivalve growth compared to the trematode Himasthla interrupta on growth of Cerastoderma edule in controlled experiments, where only a very subtle effect on growth was observed (Wegeberg \& Jensen 2003). H. interrupta does not grow in its second intermediate host and inhabits other tissues (mainly the foot), and thus does not interfere with it's host's feeding. In another marine bivalve species serving as second intermediate host, the green mussel Perna perna, large metacercariae of Proctoeces sp. caused a more notable reduction in growth, probably because of the immense size of the latter parasite (Calvo-Ugarteburu \& McQuaid 1998). However, enhanced growth due to metacercarial infection has also been observed (e.g. in Macoma balthica: Lim \& Green 1991). This indicates that a variety of factors determine the magnitude of trematode-induced effects on bivalve growth, e.g. size and tissue location of parasites, food supply of the host, and exploitative competition with conspecifics. Differences in food supply could have been responsible for the difference in growth of mussels at the 2 experimental sites, with the supply presumably being lower on the sand flat, which is located in the inner part of the tidal inlet at a slightly higher tidal level than the mussel bed site.

Although parasitism by Renicola roscovita metacercariae had a negative effect on mussel growth at both experimental sites, tidal height had a stronger effect, as indicated by the larger $F$-values in the ANCOVAs (Table 1). The importance of tidal height for mussel growth is well known, with long periods of immersion allowing almost continuous feeding (Baird 1966, Buschbaum \& Saier 2001). In addition, mussels at higher intertidal sites are subject to harsher environmental variables such as desiccation and temperature, than mussels at lower intertidal sites (Widdows \& Shick 1985). This may be reflected in the significant negative rela- 
tions of mussel growth with metacercarial load at the mid-intertidal sites compared to the non-significant correlations at the low-intertidal sites. Trematode infection may act as a stressor, with the strength of its effects depending on the presence of additional environmental stressors (Lafferty \& Kuris 1999). For example, infection of Cerastoderma edule by Himasthla elongata have been shown to reduce survival of infected individuals under oxygen depleted conditions, but not under normal environmental conditions (Wegeberg \& Jensen 1999).

Renicola roscovita is common in blue mussels throughout European coastal waters, and is often found in $100 \%$ of mussels on intertidal mussel beds (Lauckner 1983, Svärdh \& Thulin 1985, Buck et al. 2005). Thus its effect on mussel growth is likely to affect a large fraction of Mytilus edulis populations. The parasite loads in my experiments were lower than the several thousand metacercariae per individual host reported for many intertidal mussel beds (Lauckner 1983, Svärdh \& Thulin 1985, Buck et al. 2005). Significant negative regressions between metacercarial intensity and mussel growth at the mid-tide level indicate that effects are intensity dependent. Hence, at sites with very high $R$. roscovita loads, growth reduction should be severe. This may be a strategy by the parasite to enhance its transmission to its final bird host (Poulin 1995), since mussels may thus remain within the prey size range of the parasite's final host for a longer period of time. Common bird predators such as the eider Somateria mollissima and the oystercatcher Ostralegus haematopus are known to prefer smaller mussels (Nehls 1989, Hilgerloh 1997). However, growth reduction could also be a side effect of $R$. roscovita infection, arising from the 3 mechanisms discussed earlier (Poulin 1995). Whatever the reason, a growth reduction of up to almost $20 \%$ indicates that trematode parasites can be an important determinant of bivalve growth. This may have economic implications for mussel cultivation, which may be better situated at subtidal offshore sites, where $R$. roscovita infection does not occur (Buck et al. 2005). Alternatively, intertidal sites without the first intermediate host, Littorina littorea, may be suitable. Ecologically, the parasite mediated negative linkage to $L$. littorea is of interest because positive effects of the periwinkles are also reported for mussels - notably the scraping off of detrimental epigrowth such as barnacles (Buschbaum 2000). The effect of parasites on mussel growth may be lower than that of other factors such as salinity, temperature, current velocity, epigrowth and competition, all of which are known to influence mussel growth (Baird 1966, Okamura 1986, Seed \& Suchanek 1992, Buschbaum \& Saier 2001). However, parasite reduced growth may also indicate that parasites function as 'background' or superimposed stressors that may exert stronger effects in the long run. The $10 \mathrm{wk}$ duration of my experiments was too short to reveal long-term effects of parasites such as enhanced mortality rates. However, controlled infection and subsequent field experiments are a promising approach for revealing parasite induced, hidden determinants of bivalve growth.

Acknowledgements. I thank Sylvia Pross, Wenke Schulz and Anne Westphalen for their help in conducting the experiments. Christian Buschbaum and Karsten Reise provided valuable comments on a draft of this manuscript. Anonymous reviewers significantly helped to improve the manuscript.

\section{LITERATURE CITED}

Baird RH (1966) Factors affecting the growth and condition of mussels (Mytilus edulis L.). Fish Investig Ser II Mar Fish Minist Agric Fish Food 25:1-33

Buck BH, Thieltges DW, Walter U, Nehls G, Rosenthal H (2005) Inshore-offshore comparison of parasite infestation in Mytilus edulis: implications for open ocean aquaculture. J Appl Ichthyol 21:107-113

Buschbaum C (2000) Direct and indirect effects of Littorina littorea (L.) on barnacles growing on mussel beds in the Wadden Sea. Hydrobiologia 440:119-128

Buschbaum C, Saier B (2001) Growth of the mussel Mytilus edulis L. in the Wadden Sea affected by tidal emergence and barnacle epibionts. J Sea Res 45:27-36

Bush AO, Lafferty K, Lotz J, Shostak A (1997) Parasitology meets ecology in its own terms: Margolis et al. revisited. J Parasitol 83:575-583

Calvo-Ugarteburu G, McQuaid CD (1998) Parasitism and invasive species: effects of digenetic trematodes on mussels. Mar Ecol Prog Ser 169:149-163

Hawkins AJS, Bayne BL, Bougrier S, Héral M, Iglesias JIP, Navarro E, Smith RFM, Urrutia MB (1998) Some general relationships in comparing the feeding physiology of suspension-feeding bivalve molluscs. J Exp Mar Biol Ecol 219:87-103

Hilgerloh G (1997) Predation by birds on blue mussel Mytilus edulis beds of the tidal flats of Spiekeroog (southern North Sea). Mar Ecol Prog Ser 146:61-72

Hughes R, Answer P (1982) Growth, spawning and trematode infection of Littorina littorea (L.) from an exposed shore in North Wales. J Molluscan Stud 48:321-330

Lafferty KD, Kuris AM (1999) How environmental stress affects the impacts of parasites. Limnol Oceanogr 44: 564-590

Lauckner G (1980) Diseases of Mollusca: Gastropoda. In: Kinne O (ed) Diseases of marine animals, Vol 1: General aspects, Protozoa to Gastropoda. John Wiley \& Sons, New York, p 311-424

Lauckner G (1983) Diseases of Mollusca: Bivalvia. In: Kinne O (ed) Diseases of marine animals, Vol 2: Introduction, Bivalvia to Scaphopoda. Biologische Anstalt Helgoland, Hamburg, p 477-961

Lim S, Green R (1991) The relationship between parasite load, crawling behaviour, and growth rate of Macoma balthica (L.) (Mollusca, Pelycopoda) from Hudson Bay, Canada. Can J Zool 69:2202-2208

Mouritsen KN, Jensen KT (1994) The enigma of gigantism: effect of larval trematodes on growth, fecundity, egestion and locomotion in Hydrobia ulvae (Pennant) (Gastropoda: Prosobranchia). J Exp Mar Biol Ecol 181:53-66 
Mouritsen KN, Poulin R (2002) Parasitism, community structure and biodiversity in intertidal ecosystems. Parasitology 124:101-117

Mouritsen KN, Gorbushin A, Jensen K (1999) Influence of trematode infections on in situ growth rates of Littorina littorea. J Mar Biol Assoc UK 79:425-430

Nehls G (1989) Occurence and food consumption of the common eider Somateria mollissima in the Wadden Sea of Schleswig-Holstein. Helgol Meeresunters 43:27-34

Okamura B (1986) Group living and the effects of spatial position in aggregations of Mytilus edulis. Oecologia 69:341-347

Poulin R (1995) 'Adaptive' changes in the behaviour of parasitized animals: a critical review. J Parasitol 25:1371-1383

Rothschild M (1936) Gigantism and variation in Peringia ulvae Pennant 1777, caused by infections with larval trematodes. J Mar Biol Assoc UK 30:537-546

Seed R, Suchanek TH (1992) Population and community ecology of Mytilus. In: Gosling E (ed) The mussel Mytilus: ecology, physiology, genetics and culture. Elsevier Science Publisher, Amsterdam, p 87-169

Siddall R, Pike A, McVicar A (1993) Parasites of Buccinum undatum (Mollusca: Prosobranchia) as biological indicators of sewage-sludge dispersal. J Mar Biol Assoc UK 73:931-948

Editorial responsibility: Otto Kinne (Editor-in-Chief), Oldendorf/Luhe, Germany
Sousa W (1983) Host life history and the effect of parasitic castration on growth: a field study of Cerithidea californica Haldeman (Gastropoda: Prosobranchia) and its trematode parasites. J Exp Mar Biol Ecol 73:273-296

Svärdh L, Thulin J (1985) The parasite fauna of natural and farmed Mytilus edulis from the west coast of Sweden, with special reference to Renicola roscovita. Medd Havsfiskelab Lysekil 312:1-17

Villalba A, Mourelle SG, Carballal MJ, López C (1997) Symbionts and diseases of farmed mussels Mytilus galloprovincialis throughout the culture process in the Rías of Galicia (NW Spain). Dis Aquat Org 31:127-139

Wegeberg AM, Jensen KT (1999) Reduced survivorship of Himasthla (Trematoda, Digenea)-infected cockles (Cerastoderma edule) exposed to oxygen depletion. J Sea Res 42: 325-331

Wegeberg AM, Jensen KT (2003) In situ growth of juvenile cockles, Cerastoderma edule, experimentally infected with larval trematodes (Himasthla interrupta). J Sea Res 50:37-43

Widdows J, Shick J (1985) Physiological responses of Mytilus edulis and Cardium edule to aerial exposure. Mar Biol 85: $217-23$

Submitted: July 15, 2005; Accepted: January 16, 2006 Proofs received from author(s): July 28, 2006 